\title{
AN UNUSUAL SITE OF INTRA-ARTERIAL INJECTION OF THIOPENTONE
}

\author{
L.B. READY, M.D.*
}

THE DORsum of the hand provides an abundance of superficial veins for the intravenous induction of anaesthesia. Intra-arterial injection, though rare, can occur when this site is utilized.

\section{Caste FigPont}

A 60-year-old woman with carcinoma of the body of the uterus was admitted for Heyman Insertion under general anaesthesia. She was moderately obese but otherwise fit.

With a rubber tourniquet applied two inches above the wrist, an Abbott ButterAy needle, gauge *21, Internittent Infusion Set was inserted into a clearly visible vessel on the mid-dorsum of the left hand. At induction, the patient complained of pain at the injection site following the administration of $75 \mathrm{mg}$ of a 2.5 per cent solution of thiopentone. Although the injection site appeared normal, the vessel was flushed with $10 \mathrm{ml}$ of normal saline and the needle was left in situ.

Induction was completed with a further injection of 175 milligrams of thiopen* tone into the left median cubital vein. Anaesthesia was maintained with a 70 per cent nitrous oxide-orygen mixture and azeotrope halothane-ether administered by mask through a semi-closed circuit.

Following induction, a blood gas syringe was attached to the Butterfly needle at the original injection site and it filled rapidly under considerable pressure. $A$ blood gas determination yielded the following results: $\mathrm{pH}_{3} 7.35 ; \mathrm{PO}_{2}, 73 \mathrm{~mm} \mathrm{Hg}$; per cent saturation, 94 per cent; $\mathrm{Pco}_{2}, 49 \mathrm{~mm} \mathrm{Hg}$; Bicarbonate, $26.4 \mathrm{mEq} / \mathrm{L}$

\section{Discussion}

The anaesthetist is unlikely to encounter an arterial vessel in the superficial tissues on the dorsum of the hand. Consequently, this site has been recommended for the intravenous administration of thiopentone. ${ }^{1}$ Such a recommendation would seem to be justified since only one case of intra-arterial injection of thiopentone at this site has been reported. ${ }^{2}$

Arterial vessels present on the dorsum of the hand are most probably branches of the dorsal metacarpal arteries from the posterior carpal arch or of the perforating intermetacarpal branches of the deep palmar arch. Variations of the radial artery and its branches on the dorsum of the hand have been reviewed ${ }^{3}$ and account for some of the arteries found at this site.

-From the Department of Anaesthesia, University of Saskatchewan and University Hospital, Saskatoon, Saskatchewan.

657

Canad. Anaesth. Soc. J., vol. 19, no, 6, November 1972 
It has been stated that arterial pulsations may be obliterated by a "venous" tourniquet. ${ }^{4}$ Therefore, it is recommended that a careful examination of the hand be made prior to the application of a tourniquet. This is especially important in the obese patient where vessels are frequently some distance deep to the skin. Additional precautions should include the use of dilute ( 2.5 per cent) thiopentone solution and a test dose of 1 or $2 \mathrm{ml}$ followed by a pause to ensure that the injection is not painful. It has been suggested that insertion of a needle without the syringe being attached or without proximal seal permits better recognition of bright arterial blood which spurts if the tourniquet is correctly applied. ${ }^{3}$

Intra-arterial injection of thiopentone on the dorsum of the hand may produce less disastrous consequences than a similar injection higher in the arm. ${ }^{*}$ This would be expected because of the more limited distribution of the drug, since the main arterial supply to the hand and fingers is derived from the palmar arterial arches proximal to the injection site.

\section{SUMMARY}

A case of intra-arterial injection of thiopentone into the dorsum of the hand is reported. The incident was confirmed by blood gas determination on a sample from the injection site.

\section{RÉsuMé}

Nous rapportons un cas d'injection intra-artérielle de thiopentone; l'injection a été faite sur la face dorsale de la main. L'incident a été confirmé par la détermination des gaz artériels sur un ćchantillon du sang prélevé au site de l'injoction.

\section{REFERENCES}

1. Forrester, A.C. \& SAUNDERs, R.C.O. Intra-arterial thiopentone. Brit. I. Anesth. 27: 594 (1955).

2. BailLIE, T,W. Accidental intra-arterial administration of thiopental on the back of the hand. Brit. J. Anesth. 30: 373 (1958).

3. Drskpande, A.M. Accidental injection of Thialbatbitone into an anomalous radial artery. Brit. J. Anesth. 39: 83 ( 1967 ).

4. DundeE, J.W. Thiopentone and other barbiturates. 1st ed. Edinburgh and London; Livingstone (1956).

5. CoHEs, S.M. Accidental intra-arterial injection of drugs. Lancet, 255: 361,409 (1948). 